\title{
norden
}

\section{A united Nordic Region on green energy policy}

A summary from the original report

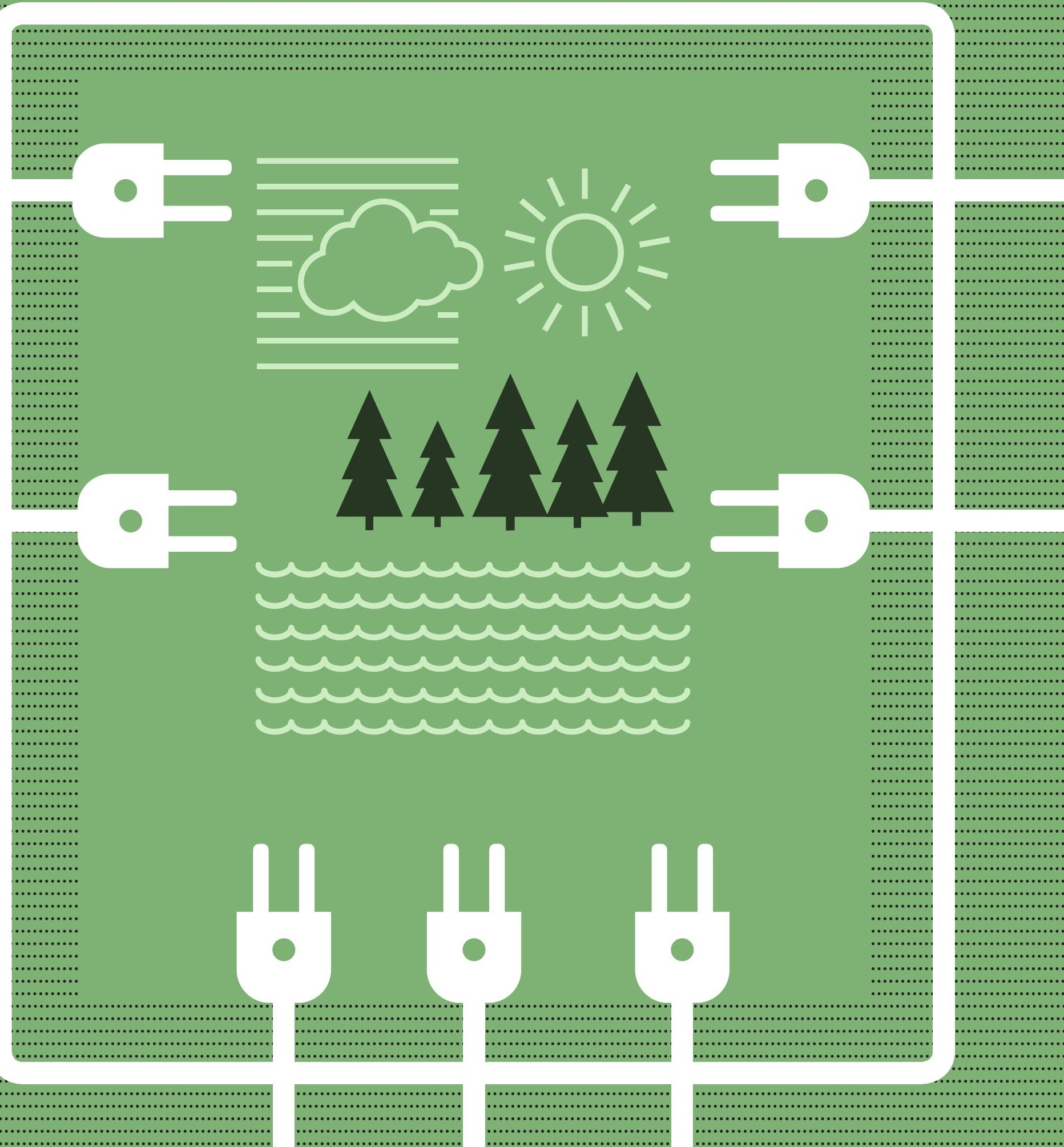


A united Nordic Region on green energy policy

A summary from the original report

ISBN 978-92-893-4718-1 (PRINT)

ISBN 978-92-893-4719-8 (PDF)

http://dx.doi.org/10.6027/ANP2016-775

ANP 2016:775

(C) Nordic Council 2016

Layout: Erling Lynder

Photos: s.4, 12 Johannes Jansson

This publication has been published with financial support by the Nordic Council. However, the contents of this publication do not necessarily reflect the views, policies or recommendations of the Nordic Council.

www.norden.org/nordpub

\section{Nordic Council}

Ved Stranden 18

DK-1061 Copenhagen K

Phone (+45) 33960200

www.norden.org

\section{Nordic co-operation}

Nordic co-operation is one of the world's most extensive forms of regional collaboration, involving Denmark, Finland, Iceland, Norway, Sweden, and the Faroe Islands, Greenland, and Åland.

Nordic co-operation has firm traditions in politics, the economy, and culture. It plays an important role in European and international collaboration, and aims at creating a strong Nordic community in a strong Europe.

Nordic co-operation seeks to safeguard Nordic and regional interests and principles in the global community. Common Nordic values help the region solidify its position as one of the world's most innovative and competitive. 


\section{A united Nordic Region on green energy policy}

A summary from the original report

1. Introduction

2. Background

3. Nordic and European co-operation on energy

4. The Nordic Council's Energy Group

5. The Energy Group's overall proposals

5.1 Joint Nordic energy research

5.2 The Nordic Region and the EU

5.3 A stronger joint Nordic electricity market

5.4 Land-based transport 10

5.5 The maritime sector 11

5.6 Energy efficiency 


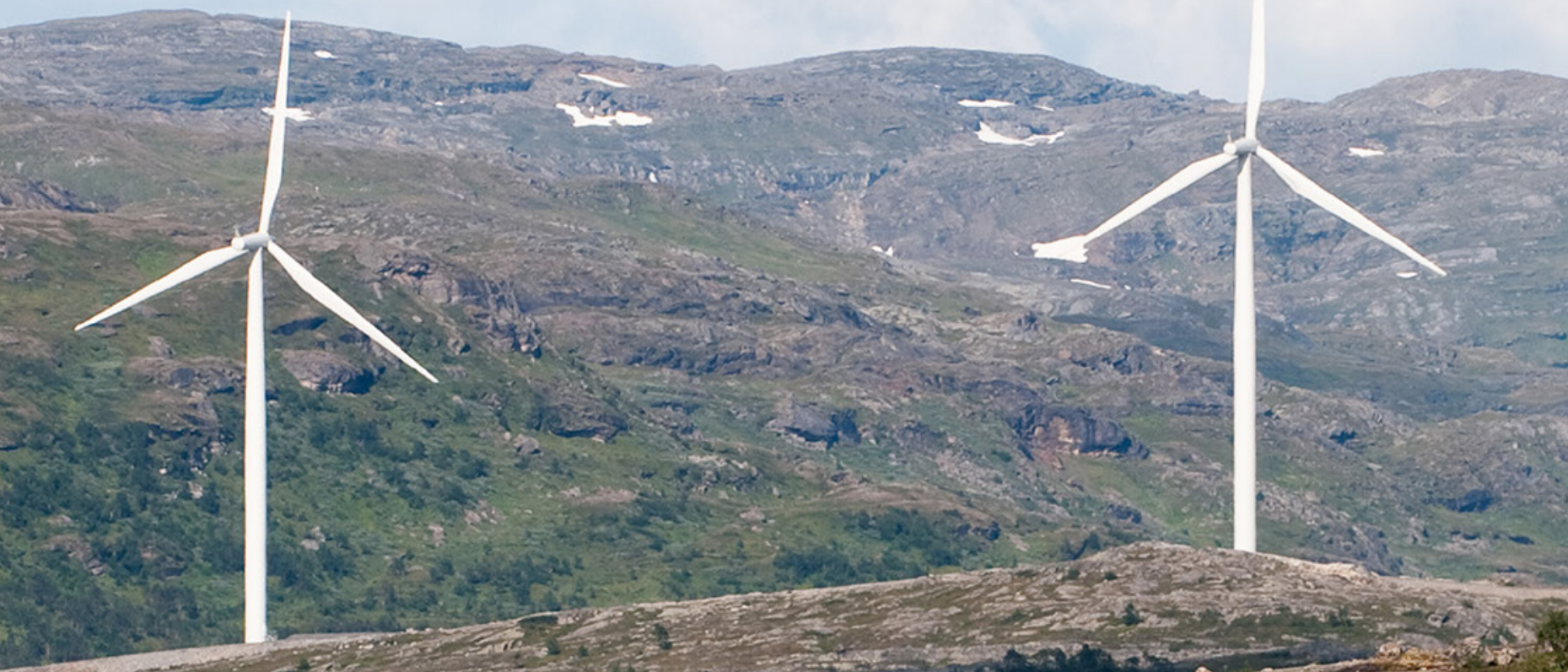

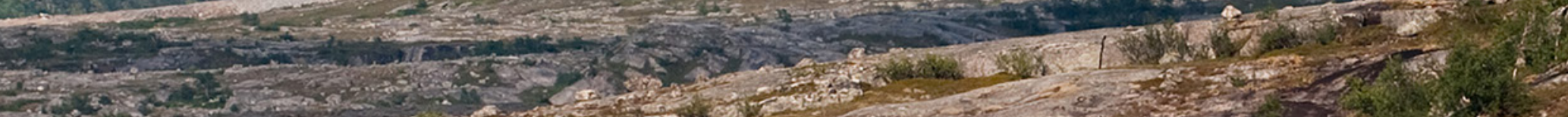

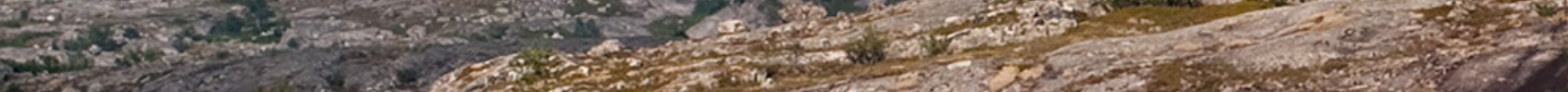

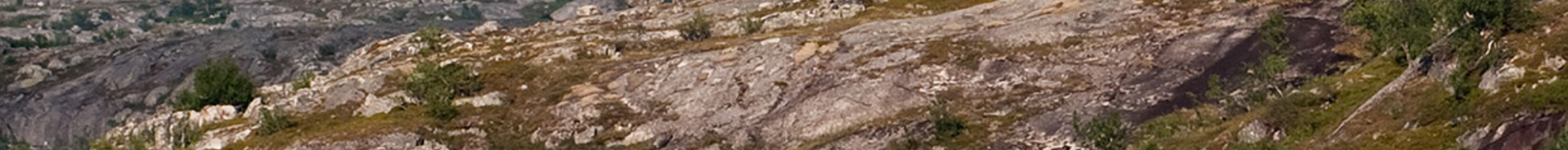

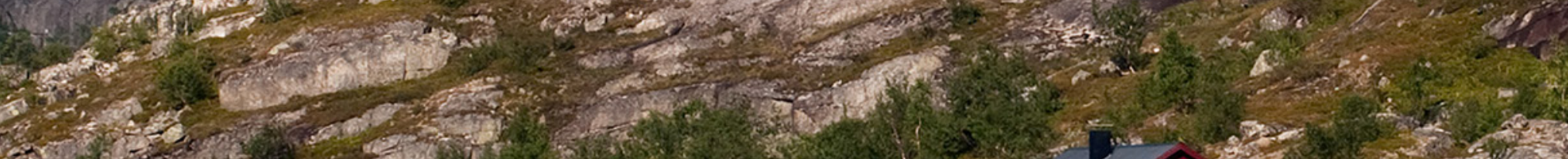

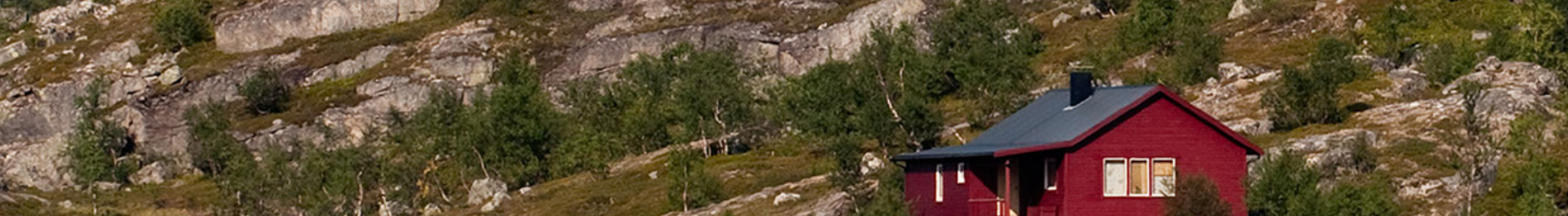

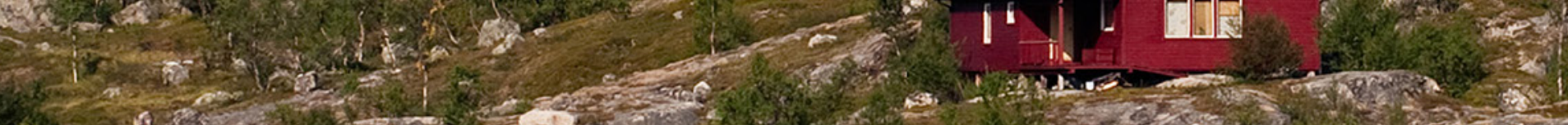

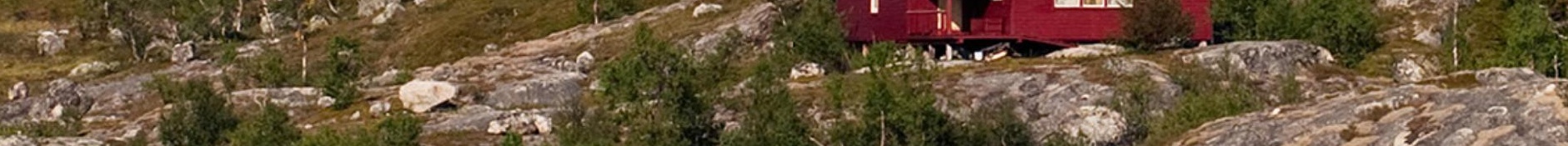

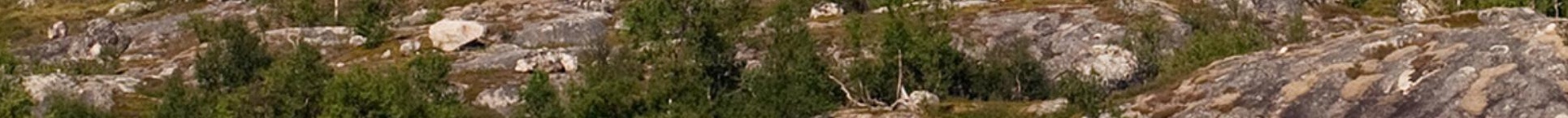

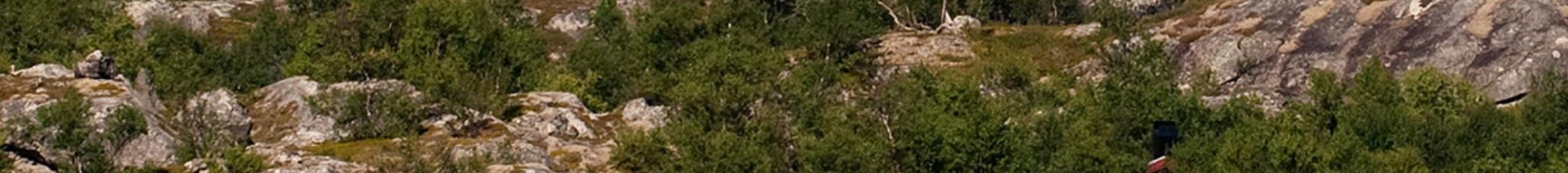

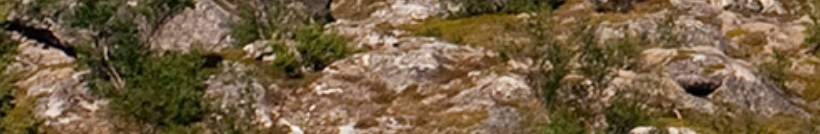

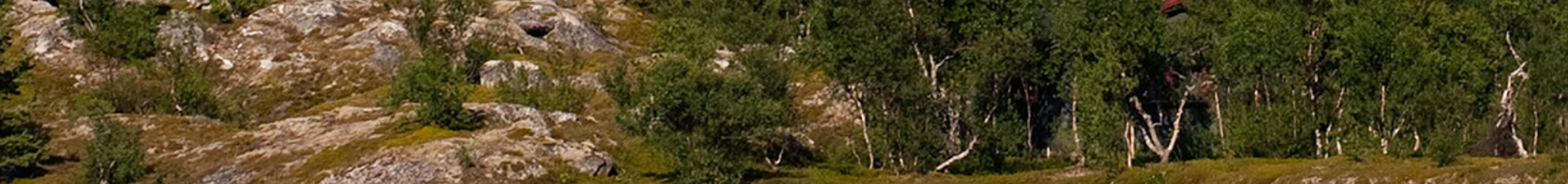

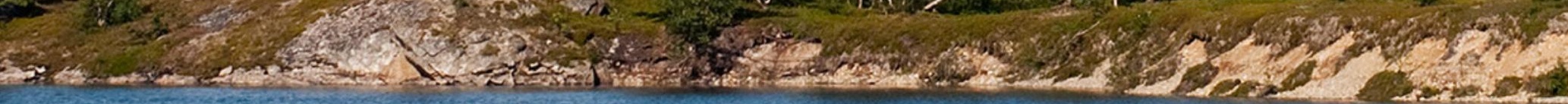




\section{Introduction}

The Nordic Region's co-operation on energy policy is long-standing and successful. Co-operation began back in 1915 when the first power cable was laid between Sweden and Denmark. 2015 was not only the 100th anniversary of the cable, it also marked the 20th anniversary of the so-called Louisiana Declaration, in which the Nordic ministers for energy articulated the vision of a free and open electricity market with effective trade between the Nordic countries.

Over the years, energy co-operation has added considerable value to the Nordic countries and autonomous regions. This co-operation is something that the Nordic countries want to take further. In 2015, the Nordic ministers for energy concluded that co-operation on energy should continue to be based on trust, solidarity, and investment in climate-friendly green growth. The ministers expressed their support for continuing to harmonise and strengthen the Nordic electricity market, but also stressed that they want to develop a co-operative relationship with the EU's forthcoming energy union.
Energy issues are also a high priority in the Nordic Council. In light of this, the Nordic Council's Environment and Natural Resources Committee and Business and Industry Committee established a working group - the Energy Group - in the spring of 2015. The group was tasked with evaluating the need for Nordic co-operation on energy policy and developing proposals for how this co-operation can be developed going forwards. The Energy Group submitted its report in the spring of 2016.

The report should be seen as an input into and inspiration for the investigative work that former Nokia Chair and CEO, Jorma Ollila is undertaking on behalf of the Nordic Council of Ministers. Ollila has been tasked with conducting a strategic review of cooperation on energy in the Nordic Region. His report is due to be completed by early 2017 and will include proposals for how co-operation on energy policy in the Nordic Region should be structured over the next 10 to 15 years. 


\section{Background}

Well-being and welfare in the Nordic countries depend on a secure, competitive, and sustainable supply of energy. Consequently, the task of producing and supplying affordable, sustainable energy is one of the biggest political challenges of our time. This task is also integral to efforts to reduce greenhouse gas emissions.

Nordic co-operation on energy draws on extensive, positive experience which clearly shows a tangible Nordic advantage in the joint development of a shared, integrated power grid, in research, and in efforts to be at the forefront of sustainable energy supplies.

The Nordic Region has the conditions to support and provide good access to renewable sources of energy, such as hydropower, wind power, geothermal energy, and bioenergy. Thanks to the Nordic Region's long-standing and ambitious policy, combined with its powerful, stable, and long-term policy instruments, the Nordic Region has become a world leader in renewable energy.

The 2009 EU Directive on renewable energy serves as the framework for the promotion of energy from renewable sources. At the Nordic level, there is value in exchanging views on how best to implement the renewables directive and in analysing issues of common Nordic interest, not least in relation to the new roadmap for a competitive low-carbon society by 2050 , which the European Commission has developed.

It is ultimately envisioned that the Nordic Region will have $100 \%$ emission-free energy, a well-integrated electricity market, including the end-user market, and adequate year-round security in its electricity supply. Efforts are also ongoing to electrify or otherwise make environmentally sustainable as many journeys and means of transport as possible. Households and industry alike have the potential to make significant energy savings.

Nordic co-operation on energy should work towards the following goals:

- A Nordic Region that explores and capitalises on the many opportunities available for developing a sustainable energy supply in the region, taking into account the different circumstances in each country.

- A Nordic Region that is a leading energy society, that is at the forefront of co-operation on energy research, and that serves as a model for successful co-operation that other regions can benefit from.

- A Nordic Region whose energy supply and consumption are carbon neutral. 


\section{Nordic and European co-operation on energy}

If the Nordic Region is to achieve these goals, energy co-operation needs to be intensified at both the Nordic and European levels. This in turn requires the Nordic countries to place greater emphasis on: changing national legislation and regulatory mechanisms; learning from one another with regard to energy-efficiency efforts in heavy industry; co-ordinating the expansion of electrified rail links across Nordic borders; and learning from one another's best practices.

The Nordic Region has the potential to become a far more significant exporter of energy. It is an uphill road towards a European energy union, yet the benefits if successful are huge. Together, the Nordic countries can contribute to the realisation of close European co-operation on energy by continuing to integrate the Nordic countries' power grids as well as integrating these with the grids of other European countries.

Broad-based European co-operation can allow for the combining of resources, such as research and demonstration projects, that the countries taken individually do not possess. The Nordic Region should strive to lead the way in showing how co-operation among countries can contribute to an affordable, sustainable supply of energy. 


\section{The Nordic Council's Energy Group}

In the spring of 2015, the Nordic Council's Environment and Natural Resources Committee and the Business and Industry Committee established a working group (the Energy Group) to evaluate the need and develop proposals for new initiatives in Nordic co-operation on energy policy. The Energy Group was instructed to focus on:

- Energy efficiency - e.g. energy efficiency in power-intensive industries and the Nordic maritime sector.

- Electrification of the transport sector.

- The transition to sustainable energy.

- Nordic energy research.

The Energy Group presented its preliminary report to each committee in Oslo on 19 April 2016. The report was also presented and discussed at an energy conference in Oslo on 20 April. It has since been updated.

The report contains over thirty proposals for initiatives that the Energy Group recommends become part of future Nordic co-operation on energy. The Energy Group highlights the following seven proposals in particular:

- For the Nordic Council of Ministers to be provided with a clear mandate to co-ordinate and bolster the Nordic Region's joint energy policy in relation to the EU, and for sufficient resources to be earmarked for the Secretariat of the Nordic Council of Ministers in order that it can regularly investigate and define Nordic interests in various, often alternative, energy policy proposals at an EU level.

- For Denmark, Finland, Norway, and Sweden to work together to develop a harmonised market-based system to promote the generation of renewable energy that can be used by all the Nordic countries.

- For a joint Nordic model/standard to be developed for electric charging stations for the rapid charging of various modes of transport (ships, ferries, cars, trucks, busses, etc.). A Nordic/standard could prove useful in the development of a broader European standard/model.

- For a long-term co-operation programme to be created for the development of electric-powered ferries for Nordic coastal services.

- For a joint Nordic energy efficiency programme to be developed for energyintensive industries, based on the positive experiences of Norway and Sweden.

- For operational Nordic co-operation to be intensified and synchronised in order to establish a joint Nordic end-user market for energy.

- For Nordic Energy Research to be given sufficient basic funding by the Nordic Council of Ministers, and for national contributions to immediately be increased proportionally in order to, for example, implement several research initiatives that the group has identified as being important for the development in the Nordic Region. 


\section{The Energy Group's overall proposals}

The proposals put forward by the Energy Group are concrete and provide guidance as to how future co-operation on energy could be developed. The proposals are split into groups under the following headings: joint Nordic energy research; the Nordic Region and the EU; a stronger joint Nordic electricity market; landbased transport; the maritime sector; energy efficiency; and climate and energy measures in Nordic cities. Each area is presented below.

\subsection{Joint Nordic energy research} Energy research in the Nordic Region currently accounts for just one per cent of total energy research in the $O E C D$, while Nordic Energy Research's energy research accounts for just one per cent of total energy research in the Nordic Region.

Consequently the Energy Group proposes that Nordic Energy Research is awarded sufficient basic funding by the Nordic Council of Ministers as well as increased national contributions. Nordic Energy Research has become smaller in relative terms, despite an evaluation indicating that the organisation provides positive results. The Energy Group believes that if the Nordic countries co-operate on energy research funding, they can benefit more from public budgets for energy research and that Nordic Energy Research will be able to play a more central role in this. A greater share of the funds for national energy research should be channelled into joint Nordic energy research.

The Energy Group also wants to see a greater focus on research into energy storage in the Nordic Region, proposing the mapping of future energy storage needs and the strengthening of joint Nordic research into the storage of renewable energy.

\subsection{The Nordic Region and the EU} With regard to co-operation with the EU, the long tradition of Nordic co-operation serves as a sound basis for increased Nordic co-ordination with EU energy policy (the EU Energy Union). The Nordic countries can and should be a powerful voice for an open European energy market and the use of economic controls for a transition to an emissions-neutral energy system.

There are several pieces of EU legislation affecting the energy policies of the Nordic countries with regard to both energy markets and energy efficiency. All of the Nordic countries are subject to EU/EEA legislation on energy labelling and ecodesign. There is also an energy efficiency directive that aims to create an energy efficiency framework. The directive applies to industry, households, the public sector, and energy companies. Additionally, all the Nordic countries are subject to the EU's emission quota trading system - the ETS system.

The Nordic Region has large reserves of bioenergy. For this reason, it is important that the Nordic countries work to ensure that criteria for sustainable bioenergy/ biomass are developed at both the EU and the global levels to ensure that the competitiveness of the Nordic bioenergy sector is not put at risk.

There is a constant exchange of experience at the Nordic level regarding the implementation of EU directives once they come into effect and the analysis of their consequences. The Nordic action plan on energy co-operation for 2014-2017 states that, where appropriate, it may be necessary to develop joint Nordic positions ahead of EU decisions. A growing EU focus on energy policy and a number of new legislative measures are expected in the coming years. 
The Energy Group believes that the Nordic electricity market has the potential to expand to include other countries. The group proposes that the Nordic Council of Ministers be given a clear mandate to co-ordinate and bolster the Nordic Region's joint energy policy in relation to the EU. Furthermore the Nordic Council should uphold dialogue with members of the European Parliament regarding European energy policy.

Moreover, the Energy Group wants to strengthen energy co-operation with the Baltic countries and Poland, as well as see the continuation of energy co-operation in the Baltic Sea Region under the name BASREC and/or Plan BEMIP.

\subsection{A stronger joint Nordic electricity market}

Nordic electricity producers and electricity consumers are linked by a shared power grid. The Nordic countries have different systems for promoting the production of renewable energy. Sweden and Norway have a market-based certification system. Denmark and Finland use systems with many common features that are based on fixing producers' prices in relation to production methods (feed-in tariffs and premium feed-in tariffs). An analysis ordered by the Nordic Council of Ministers in 2008 stated that the use of marketbased controls could help the Nordic countries to achieve significant savings in the investments required to achieve renewable energy targets. It is anticipated that the EU will work towards greater harmonisation in funding schemes as part of the ongoing process to implement the EU Energy Union.

The joint Nordic electricity market has been instrumental in each Nordic country achieving its renewable energy targets cost-effectively. Ensuring a growing supply of electricity from wind and solar sources is a challenge that shows no sign of abating. Consequently, it is necessary to strengthen power grid links between the Nordic countries.
Denmark, Finland, Norway, and Sweden aspired to create an operational joint Nordic end-user market for electricity in 2015. Although the groundwork is largely complete, not all the countries have implemented the national measures necessary to realise these political goals. Further political pressure is needed to achieve a harmonised market-based system.

Alongside a joint market-based system, the Energy Group proposes that the Nordic countries, in collaboration with the Nordic systems operators (TSOs), develop a joint strategy for the expansion of grid interconnectors among the countries, and between the Nordic countries and neighbouring countries.

Additionally, the group wants the countries to intensify and synchronise operational Nordic co-operation to establish a joint Nordic end-user market for energy, which will also help to ensure a reliable and stable supply of energy.

\subsection{Land-based transport}

The Nordic Region has the potential to lead the way in low-emission or zero-emission land-based transport. The installation of charging stations for rapid charging is decisive in making electric cars an attractive option also outside of the major cities.

Since vehicle manufacturers and those installing charging-stations (which dramatically change the scope of use of electric cars) are interdependent, it would be useful if a standard was adopted to enable a quicker rate of conversion. In addition to a Nordic standard for charging stations, the group proposes that the Nordic Swan ecolabel be used to certify logistics companies, and that transport policies and taxation policies in the Nordic Region be developed with a view to favouring low-emission or zero-emission transport. 


\subsection{The maritime sector}

Nordic shipping companies own approximately 20 per cent of the world's shipping fleets. Consequently, the Nordic countries have a special responsibility for leading the way when it comes to developing more energy-efficient maritime transport that emits lower levels of carbon dioxide.

The Energy Group proposes that the Nordic Region's major ports join forces to develop a joint incentive structure for green maritime transport, and work together to develop electric ferries for the region's coastal services. The group also wants to see efforts regarding a shift towards alternative energy sources, such as hydrogen, for the Nordic Region's fishing and coastal fleets.

\subsection{Energy efficiency}

With the exception of Denmark, energyintensive industries are relatively prominent in the Nordic Region as compared to the EU. The Energy Group emphasises the positive results achieved with regard to energy efficiency in Norway and Sweden, and proposes the development of a joint Nordic energy efficiency programme for energy-intensive industries based on the experiences of these two countries.

In addition, the Energy Group points to the huge potential for better energy efficiency in the construction sector, and propose the prioritisation and intensification of efforts to harmonise regulations and standards for the Nordic housing and construction sector. With regard to climate and energy initiatives in the Nordic cities, the Energy Group calls on the cities to share their knowledge and experience of sustainable energy solutions for transport and buildings. 
0 


\section{The Energy Group consisted of the following members:}

From the Committee for Growth and Development in the Nordic Region

Lena Asplund (chair, Sweden)

Ruth Mari Grung (Norway)

From the Committee for a Sustainable Nordic Region

Mikko Kärnä, (Finland)

Per-Rune Henriksen (Norway) (until October 2015)

Senior advisors Johan Lindblad and Tryggvi Felixson, and co-ordinator from the Nordic Council, Bente $\emptyset x$ seth, acted as the secretariat to the group.

The two committees endorse the report's conclusions.

This is an English translation of a summary from the original report.

The full report can be read here:

http://norden.diva-portal.org/smash/record.jsf?pid=diva2\%3A943530\&dswid=-6547 


\section{norden}

Nordic Council

Ved Stranden 18

1061 Copenhagen $\mathrm{K}$

www.norden.org

Energy issues are also a high priority in the Nordic Council. In light of this, the Nordic Council's Environment and Natural Resources Committee and Business and Industry Committee established a working group - the Energy Group - in the spring of 2015. The group was tasked with evaluating the need for Nordic co-operation on energy policy and developing proposals for how this co-operation can be developed going forwards. The Energy Group submitted its report in the spring of 2016.

The proposals put forward by the Energy Group are concrete and provide guidance as to how future co-operation on energy could be developed. 